\title{
CAMERA TRAPS AS A TOOL FOR CARNIVORE CONSERVATION IN A MOSAIC OF PROTECTED AREAS IN THE PANTANAL WETLANDS, BRAZIL
}

\author{
Grasiela Porfirio $^{1,2^{*}}$, Vania C. Foster ${ }^{3}$, Pedro Sarmento ${ }^{1}$, Carlos Fonseca ${ }^{1}$ \\ ${ }^{1}$ University of Aveiro, Portugal \\ e-mail:sarmentop@gmail.com,cfonseca@ua.pt \\ ${ }^{2}$ Dom Bosco Catholic University, Brazil \\ e-mail:*grasi_porfirio@hotmail.com \\ ${ }^{3}$ Federal University of Mato Grosso do Sul, Brazil \\ e-mail:vaniafoster@hotmail.com
}

Received: 26.01.2018

\begin{abstract}
Although known globally for its biodiversity, only around 5\% of the Brazilian Pantanal is protected. The Network for Protection and Conservation of Amolar Mountain Ridge is an informal initiative that legally protects over 2000 $\mathrm{km}^{2}$ of the Pantanal biome. Several camera-trapping surveys were carried out at Amolar Mountain Ridge from August 2011 to September 2013 in order to increase our knowledge of the species occurrence and its ecological requirements. The aims of this study were : 1) to inventory the carnivore species occurring within this network of protected areas; 2) to describe their activity patterns and 3) to discuss threats for those species' conservation in the region. We used the Kernel density method to describe the species' activity patterns. We obtained 764 records (from 12703 camera-days) of eight carnivores, including endangered species in Brazil, such as the jaguar (Panthera onca), puma (Puma concolor), and ocelot (Leopardus pardalis), that were among the most frequently recorded by camera traps. The other species detected were the South America coati (Nasua nasua), the tayra (Eira barbara), the crab-eating raccoon (Procyon cancrivorus) and the jaguarundi (Puma yagouaroundi). We provided information on activity patterns of the jaguar and puma, which exhibited cathemeral activity patterns, on the ocelot and crab-eating fox, which were mostly nocturnal, and on the Southern coati and jaguarundi, which were diurnal. Scansorial and species that occur naturally in low densities as the tayra and the crab-eating raccoon were difficult to be detected with the used camera trapping setting. However, due to the natural characteristics of the study area, camera trapping is among the most appropriate tools for providing data about carnivores and their prey. This information is essential to delineate conservation plans for Amolar Mountain Ridge.
\end{abstract}

Key words: activity patterns, camera trapping, carnivores, conservation biology, species inventory

\section{Introduction}

The Pantanal biome is considered to be the largest seasonal floodplain in the world, covering territories in the South American countries of Brazil, Bolivia and Paraguay. The Brazilian Pantanal, which is located in the states of Mato Grosso and Mato Grosso do Sul, encompasses the largest area (approximately $140000 \mathrm{~km}^{2}$ ) (Junk et al., 2006). The biome comprises a complex mosaic of habitats, being influenced by neighbouring biomes such as the Cerrado, Amazon Forest and Chaco, which contributes to a high environmental diversity (MMA, 2006).

Due to its attributes and conservation value, the Pantanal was proclaimed as a region of «National Heritage» in the Brazilian Constitution in 1988. The UNESCO recognised it as a Ramsar Site in 1993 and as a World Biosphere Reserve in 2000. Also in 2000, the UNESCO accredited the Pantanal a Natural World Heritage Certificate (Junk et al., 2006). Despite its great diversity and environmental importance, about $95 \%$ of the land in the Pantanal is privately owned, where the main economic activity is cattle ranching (Crawshaw \& Quigley, 1991; Seidl et al., 2001). Consequently, less than $5 \%$ of the Brazilian Pantanal is protected (Crawshaw \& Quigley, 1991; Harris et al., 2005).

Implementation of protected areas in localities possessing relevant biological attributes has been one of the main strategies for safeguarding biodiversity (Alho \& Sabino, 2011; Lourival et al., 2011). In an attempt to protect this greatly biodiverse biome, some landowners have joined forces to create an informal mosaic of protected areas called the «Network for Protection and Conservation of Amolar Mountain Ridge». This mosaic legally protects over $2000 \mathrm{~km}^{2}$ of the Pantanal biome (Bertassoni et al., 2012), representing 7\% of the total area of private reserves in Brazil (IHP, unpublished data). The Amolar Mountain Ridge is located in the Paraguay sub-region of the Pantanal in the state of Mato Grosso do Sul, extending northwest for about $40 \mathrm{~km}$ along the Bolivian border to the border of Mato Grosso in Brazil. Due to its uniqueness, the Environment Ministry of Brazil considers the Amolar Mountain Ridge and 
its surroundings as an important area, endowing it with a high priority for biodiversity conservation (MMA, 2007). Therefore, knowledge of its regional biodiversity is critical to implementing better conservation strategies.

Carnivores are essential to ecosystem balance, but several species are threatened worldwide, mainly due to anthropogenic activities (SilleroZubiri et al., 2004; Loveridge et al., 2010; IUCN, 2018). Detecting terrestrial carnivores can be a challenge, especially in vast and densely vegetated protected areas, due to their secretive and mainly nocturnal behaviour and the low population densities of most species. Camera trapping has proved to be one of the most useful tools for wildlife surveys as it is non-invasive and provides information on cryptic and inconspicuous species (Harmsen et al., 2009; Sarmento et al., 2009; Surnato et al., 2013). Data obtained from camera trapping can be used to study several topics of animal ecology such as inventories (Srbek-Araujo \& Chiarello, 2005; Tobler et al., 2008), site occupancy (Mackenzie \& Royle, 2005; O'Connell et al., 2006; Rich et al., 2013), patterns of spatial partitioning among species (Sarmento et al., 2011; Sollmann et al., 2012), temporal interactions between species as well as activity patterns (Foster et al., 2013; Frey et al., 2017). In the last two decades, several factors contributing to Neotropical carnivore coexistence have been studied using camera trapping (Vieira \& Port, 2007; Di Bitetti et al., 2010; Bianchi et al., 2016). Additional applications of camera trapping include estimation of relative densities of elusive species (Royle et al., 2005; Mackenzie et al., 2006), identification of critical habitats for threatened species and predicting their population trends (McCarthy et al., 2015).

Protected areas play an important role in the conservation of Neotropical carnivores, since most carnivores have large home ranges, need high quality habitats, and a broad and abundant prey base (De Ângelo et al., 2011; De la Torre et al., 2017). Thus, this study aimed 1) to list the carnivore species that occur in the network of protected areas, 2) to describe their activity patterns, and 3) to discuss threats for those species conservation in the region.

\section{Study site}

\section{Material and Methods}

The study was carried out at two adjacent sites in the Network for Protection and Conservation of Amolar Mountain Ridge: Santa Tereza Ranch (STR) and Engenheiro Eliezer Batista Protected
Area (EEB), comprising an area of $830 \mathrm{~km}^{2}$. Amolar Mountain Ridge is located in the Upper Paraguay River Basin of the western Brazilian Pantanal. The climate is considered seasonal and as tropical savannah (AW) according to the Köppen classification (Cadavid-Garcia, 1984), with hot and humid conditions in summer and dry and cold during winter. The main vegetation types at both sites are pioneer herbaceous formations $(50 \%)$ that can be submerged during the flooding periods, seasonal semi-deciduous alluvial forest (11\%), and seasonal deciduous sub-montane forest (19\%). Permanent rivers and lakes cover approximately $20 \%$ of both areas (Porfirio et al., 2014).

\section{Data collection}

We carried out six surveys between August 2011 and September 2013. In the first, fourth and sixth survey cameras were spaced $500 \mathrm{~m}$ apart, while in the second and third survey cameras were spaced $1500 \mathrm{~m}$ apart, and in the fifth survey camera were distant $2000 \mathrm{~m}$ each other (Fig. 1). Each station consisted of one camera trap, which was placed at a distance of $40-50 \mathrm{~cm}$ above the ground and 2-3 $\mathrm{m}$ away from the trail along dirt roads, river margins, within the forest, and in open habitats in order to sample different habitats and carnivore species of the protected area. We used Bushnell Trophy Cam (Bushnell ${ }^{\circledR}$, Kansas, USA) and Panthera V3 (Panthera, New York, USA) digital cameras. The cameras operated 24 hours/day, with 30 -second intervals between pictures, and were checked at 15-30 day intervals to download pictures and to change batteries. A total of 119 camera trap stations were established (minimum of 9 camera traps/survey to maximum of 41 camera traps/survey). Surveys were carried out over 562 days, representing 12703 cameradays of sampling effort.

\section{Data analysis}

The identification of carnivore species was carried out following Lima-Borges and Tomas (2004), and by using the drawings from Eisenberg $\&$ Redford (1999). A species accumulation curve was built using the package vegan in the software $\mathrm{R}$ version 3.0.0 (R Development Core Team, 2013). An interval of $24 \mathrm{~h}$ between records was given in order to guarantee independence of records of the same species. This premise was not followed when it was possible to identify different individuals, in which case each one was considered an independent record (Ross et al., 2013). 


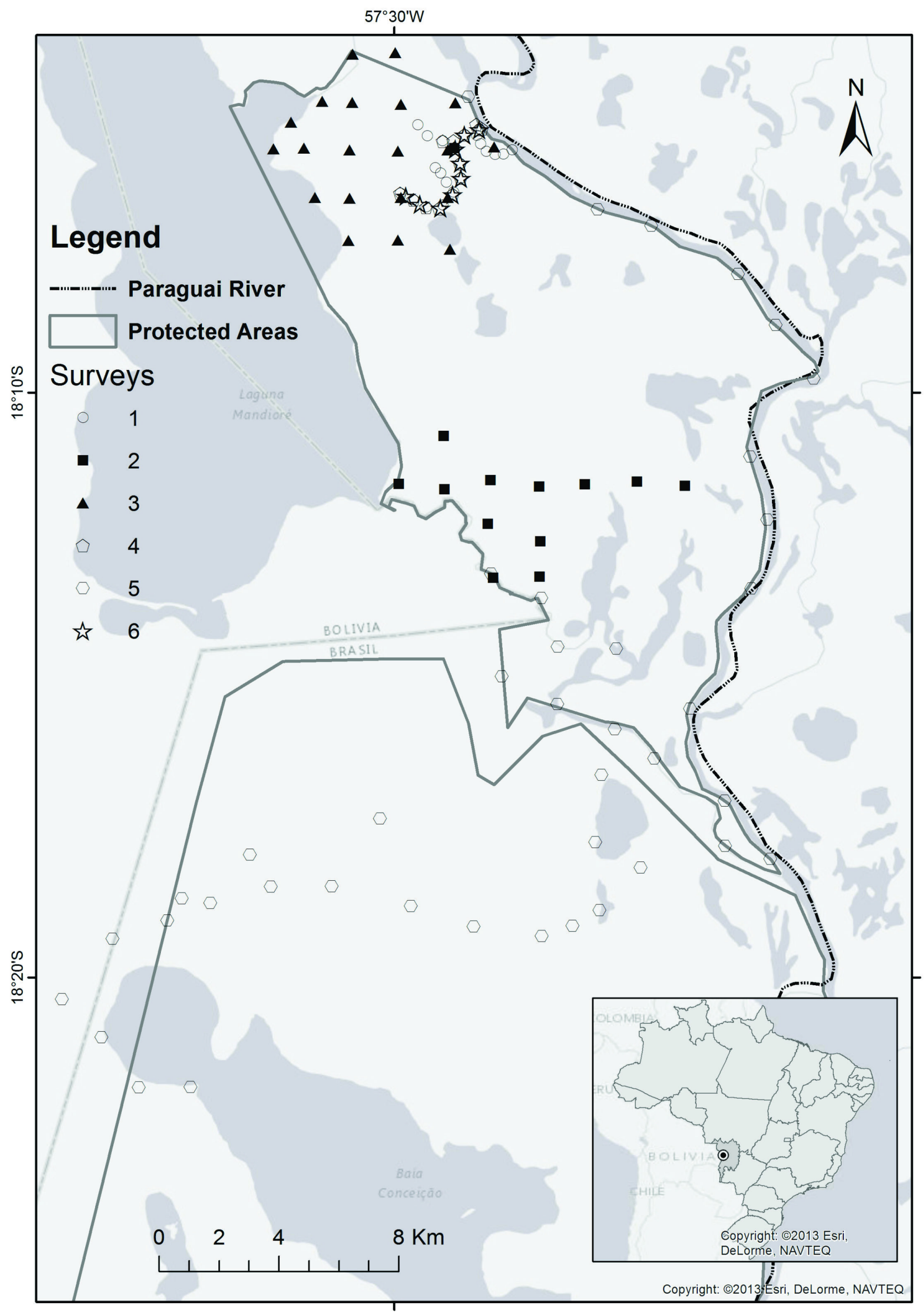

Fig. 1. Map of the study sites located in Engenheiro Eliezer Batista Protected Area and Santa Tereza Ranch (Brazilian Pantanal), indicating the different camera trapping surveys carried out from August 2011 to September 2013. The gray shades mean water (rivers, lakes and water bodies). (According to Porfirio et al. (2016a), with modifications). 
To describe carnivore activity patterns, we used pictures taken at least one hour apart for each species. Because of the proximity of camera traps in the first, fourth and sixth survey, only the first record per hour per camera site was used as a detection event in each $24 \mathrm{~h}$ period. The remaining records were eliminated from the analysis to reduce bias (Ross et al., 2013). Then, the time of each picture was converted to solar time (Foster et al., 2013; Porfirio et al., 2016a), and observations were classified as diurnal (activity predominantly between $1 \mathrm{~h}$ after sunrise and $1 \mathrm{~h}$ before sunset), nocturnal (activity predominantly between $1 \mathrm{~h}$ after sunset and $1 \mathrm{~h}$ before sunrise) or crepuscular (period that last $1 \mathrm{~h}$ before to $1 \mathrm{~h}$ after sunrise and sunset) following Romero-Muñoz et al. (2010). Based on the percentage of pictures in each category, species were classified as diurnal $(<15 \%$ of the observations were at night), nocturnal $(>85 \%$ of the observations were at night), mostly diurnal (15$35 \%$ of the observations were at night), mostly nocturnal $(65-85 \%$ of the observations were at night), crepuscular (50\% of the observations occurred during the crepuscular period), and the rest were classified as cathemeral (i.e. species that were active both day and night) (RomeroMuñoz et al., 2010; Foster et al., 2013). These analyses were also performed in the software $\mathrm{R}$, using the approach developed by Ridout \& Linkie (2009).

\section{Results and Discussion}

We obtained a total of 764 records of eight carnivore species (Fig. 2, Table 1). The crabeating fox Cerdocyon thous Linnaeus, 1766 (n $=385$ ) and the ocelot Leopardus pardalis (Linnaeus, 1758) $(\mathrm{n}=176)$ were the most recorded species, whereas the least recorded species were the tayra Eira barbara (Linnaeus, 1758) $(\mathrm{n}=4)$ and the crab-eating raccoon Procyon cancrivorus (C. Cuvier, 1798) $(\mathrm{n}=2)$.

We were able to describe activity patterns for the crab-eating fox, ocelot, jaguar Panthera onca (Linnaeus, 1758), puma Puma concolor (Linnaeus, 1771), Southern Coati Nasua nasua (Linnaeus, 1766), and jaguarundi Puma yagouaroun$d i$ (É. Geoffroy, 1803), due to the low number of records for the other species. Both the crabeating fox and the ocelot were mostly nocturnal, jaguars and pumas displayed cathemeral activity patterns, whereas Southern Coati and jaguarundi were diurnal (Fig. 3).
To date, 174 species of mammals have been recorded in the Pantanal, of which 20 are carnivores (Alho et al., 2011). Therefore, we recorded $40 \%$ of the carnivores known to occur in the Pantanal. Nevertheless, our accumulation curve showed an asymptotic trend, demonstrating that we detected the majority of terrestrial carnivore species occurring in the study area (Fig. 4). Considering solely the protected areas of STR and EEB, our camera traps recorded $80 \%$ of the carnivore species registered (Porfirio et al., 2014), only failing to detect aquatic carnivorous species.

Several studies have demonstrated the efficiency of camera traps for detecting terrestrial mammals (Silveira et al., 2003; Lyra-Jorge et al., 2008; Carvalho et al., 2013). Furthermore, studies have also demonstrated the potential of this tool for recording and studying arboreal and aquatic species, such as marsupials, rodents and primates (Oliveira-Santos et al., 2008; Leuchtenberger et al., 2014; Bowler et al., 2017). As camera traps were set in trails, some species of carnivores were favoured in terms of detection, as crab-eating foxes, ocelots and jaguars (Tobler et al., 2008; Harmsen et al., 2010). Our study revealed a high number of records from crab-eating fox and ocelot, followed by the jaguar, whereas the tayra and crab-eating raccoon, which use less the trails and dirt roads, were less detected (Harmsen et al., 2010). Crab-eating foxes and ocelots are common and abundant in the Pantanal (Bianchi et al., 2014), and this area is also considered one of the main strongholds for jaguars (Zimmermann et al., 2005). Moreover, dense habitats close to water and with prey abundance favour the jaguar's presence (Emmons, 1987; Crawshaw \& Quigley, 1991). In contrast, our study area does not seem to be suitable for pumas, which have a preference for drier habitats (Núñez et al., 2000). We are somewhat surprised by the few records of South American coati Nasua nasua, since this species is one of the most common in other subregions of the Pantanal (such as Nhecolândia), but this may have been because of its preference for savannas (Bianchi et al., 2016). The scansorial behaviour of tayras probably explains their lower detection (Asensio \& Gómez-Marín, 2002). As for other studies carried out in the Pantanal, the crab-eating raccoon and jaguarundi Puma yagouaroundi presented one of the lowest capture success rates (Bianchi et al., 2016), most likely due to its secretive habits and low densities. 

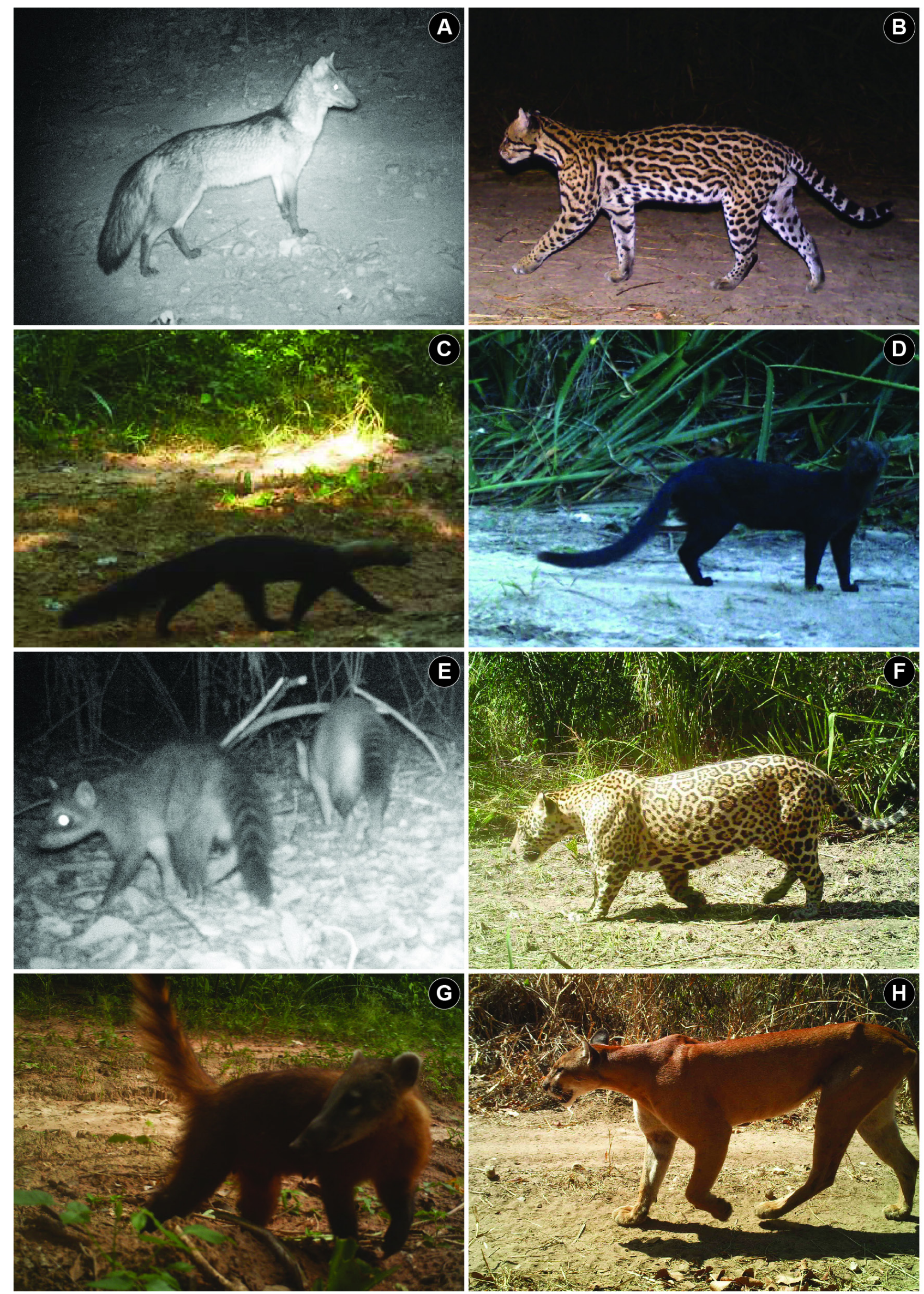

Fig. 2. Carnivore species detected in camera trapping surveys carried out in Engenheiro Eliezer Batista Protected Area and Santa Tereza Ranch within the Brazilian Pantanal between August 2011 and September 2013. A. Crab-eating fox (Cerdocyon thous); B. Ocelot (Leopardus pardalis); C. Tayra (Eira barbara); D. Jaguarundi (Puma yagouaroundi); E. Crab-eating raccoon (Procyon cancrivorus); F. Jaguar (Panthera onca); G. Southern Coati (Nasua nasua); H. Puma (Puma concolor). 
Table 1. List of species, number of records, common names, habitat types, and conservation statuses according to the IUCN Red List (IUCN, 2018) for carnivores identified in Engenheiro Eliezer Batista Protected Area and Santa Tereza Ranch within the Brazilian Pantanal between August 2011 and September 2013

\begin{tabular}{|c|c|c|c|c|}
\hline Scientific Name & Common name & $\mathrm{n}$ of records & Habitat type & $\begin{array}{c}\text { Conservation } \\
\text { status }\end{array}$ \\
\hline Cerdocyon thous Linnaeus, 1766 & Crab-eating fox & 385 & GF, DS, SDF, SSF & $\mathrm{LC}$ \\
\hline Leopardus pardalis (Linnaeus, 1758) & Ocelot & 176 & $\begin{array}{l}\text { GF, RF, DS, HS, } \\
\text { SDF, SSF }\end{array}$ & $\mathrm{LC}$ \\
\hline Panthera onca (Linnaeus, 1758) & Jaguar & 122 & RF, GF, HS, SSF & NT \\
\hline Puma concolor (Linnaeus, 1771) & Puma & 47 & SDF, SSF & $\mathrm{LC}$ \\
\hline Puma yagouaroundi (É. Geoffroy, 1803) & Jaguarundi & 15 & SSF & $\mathrm{LC}$ \\
\hline Nasua nasua (Linnaeus, 1766) & Southern Coati & 13 & DS, SDF, SSF & $\mathrm{LC}$ \\
\hline Eira barbara (Linnaeus, 1758) & Tayra & 4 & SDF, SSF & $\mathrm{LC}$ \\
\hline Procyon cancrivorus (C. Cuvier, 1798) & Crab-eating raccoon & 2 & SSF & $\mathrm{LC}$ \\
\hline
\end{tabular}

Note: GF - Gallery Forest, RF - Riparian Forest, DS - Dry Savannah, HS - Humid Savannah, SDF - Seasonal Deciduous Forest, SSF - Seasonal Semi-deciduous Forest; LC - Least Concern, NT - Near Threatened.
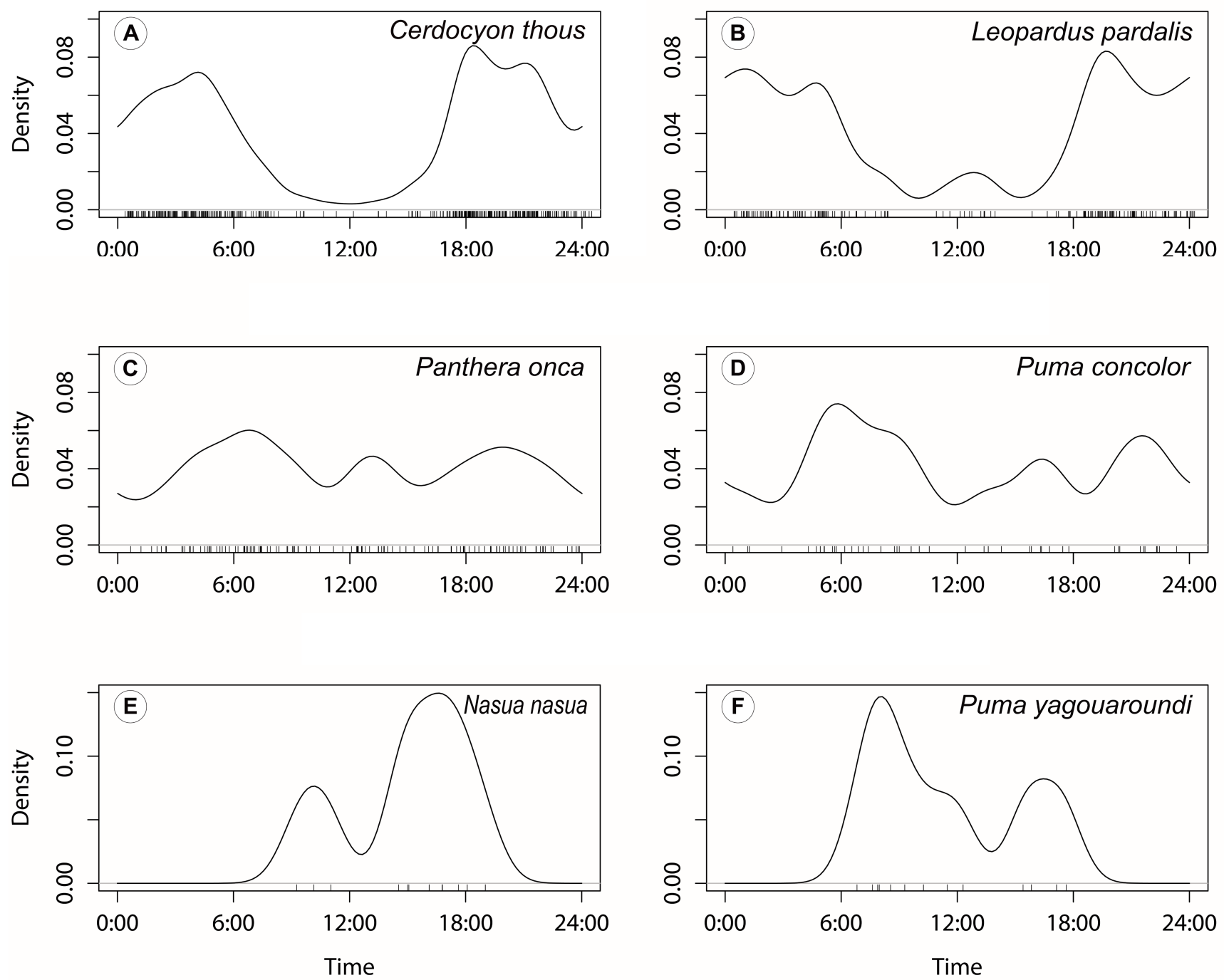

Fig. 3. Kernel densities of activity patterns of the most detected carnivore assemblage in Engenheiro Eliezer Batista Protected Area and Santa Tereza Ranch (Brazilian Pantanal) between August 2011 and September 2013. Short vertical lines indicate individual records of species. Designations: A. Crab-eating-fox (Cerdocyon thous); B. Ocelot (Leopardus pardalis); C. Jaguar (Panthera onca); D. Puma (Puma concolor); E. Southern Coati (Nasua nasua); F. Jaguarundi (Puma yagouaroundi). 


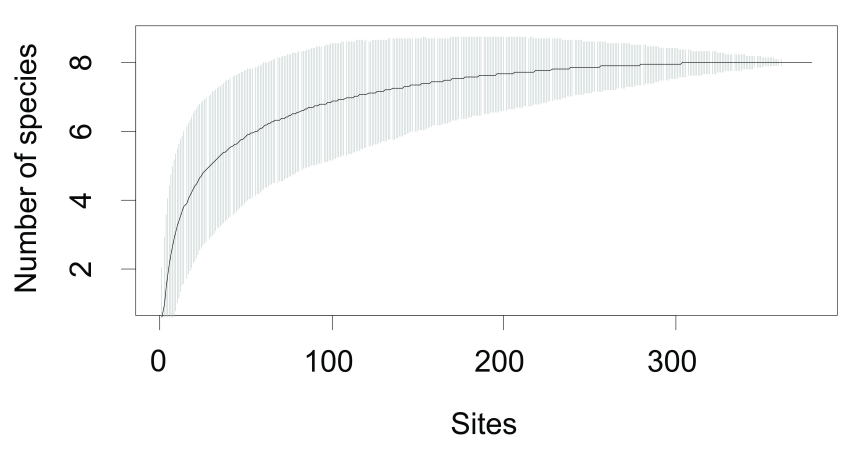

Fig. 4. Carnivore species accumulation curve obtained through randomisations of camera-trapping survey data collated from Engenheiro Eliezer Batista Protected Area and Santa Tereza Ranch (Brazilian Pantanal) from August 2011 to September 2013. Grey shaded area means the confidence intervals.

Most of the carnivores we studied followed activity patterns previously known. The mostly nocturnal activity pattern has also been reported for crab-eating foxes in the Chaco-Chiquitano Transitional Forest of Bolivia (Maffei et al., 2002), in northeastern Argentina (Di Bitetti et al., 2009) and in southeastern Brazil (Vieira \& Port, 2007). Ocelots were predominantly nocturnal in our study area, as also reported for the Bosque Chiquitano of Bolivia (Maffei et al., 2002), the Bolivian Amazon (Gómez et al., 2005), the Atlantic Forest of Argentina (Di Bitetti et al., 2006), and the Peruvian Amazon (Kolowski \& Alonso, 2010). This nocturnal behaviour of ocelot may reflect the activity of their favourite small prey (Bianchi et al., 2014), which also tends to be nocturnal (Emmons, 1987). In fact, Porfirio et al. (2016a) demonstrated that ocelots tend to tailor their activity to that of their potential prey, probably in an attempt to increase encounters. Jaguars in Amolar Mountain Ridge exhibited cathemeral behaviour, a pattern different of the observed in other areas of the Pantanal (Crawshaw \& Quigley, 1991; Foster et al., 2013). Pumas were also cathemeral, which is consistent with observations of Gómez et al. (2005) in Bolivia; although in Argentina, western Bolivia and Chile, pumas are crepuscular (Lucherini et al., 2009). As opportunistic predators, jaguars and pumas feed on a large variety of prey, but they mainly consume medium to large-sized prey (Emmons, 1987; Taber et al., 1997; Núñez et al., 2000; Monroy-Vilchis et al., 2009). Some studies have suggested that the activity patterns of these large felids may be determined by those of their main prey (Harmsen et al., 2011; Foster et al., 2013; Porfirio et al., 2017). The Southern Coati followed the diurnal pattern observed in another area of the Pantanal (Bianchi et al., 2016).
Although the jaguarundi is usually seen during the day, studies estimating the activity patterns of this species by camera traps are scarce, since it generally has low detection rates by the method, probably due to its low density.

Camera trapping can undoubtedly greatly contribute to conservation efforts. Of the eight carnivore species recorded in our study, three are considered Vulnerable according to ICMBio (2016), with the jaguar classified as Near Threatened by the IUCN (2018) (Table 2). All other species are considered Least Concern (ICMBio, 2016; IUCN, 2018). Locally, the main factors negatively affecting the biodiversity of Amolar Mountain Ridge are overfishing, unregulated tourist activities, poaching, retaliatory hunting, deforestation, logging and forest fires around the protected areas (Moreira, 2011; Bertassoni et al., 2012). Furthermore, it has been observed that the negative human perceptions and attitudes towards the felids in this region are a concern regarding their conservation (Porfirio et al., 2016b).

An improved understanding of the occurrence, biological and ecological requirements of carnivores and their prey through camera trapping studies will be useful for identifying additional areas that could be included in the Network for Protection and Conservation of Amolar Mountain Ridge, thereby enlarging its conservation coverage and effectiveness. Much of this understanding can be achieved using medium-to-long-term carnivore monitoring through occupancy and co-occurrence models (Cruz et al., 2015). This kind of monitoring indicates more than just the proportion of sites occupied by a species, since it provides data on habitat preferences, abundance estimates and patterns of species interactions and coexistence (Mackenzie et al., 2002; Royle \& Nichols, 2003; Sollmann et al., 2012). Furthermore, the characteristics of this particular protected area network can provide some relevant details about carnivore behaviours in relation to flood and drought periods (that could possibly change occupancy and activity patterns, prey availability and, consequently, interactions among species). In this context, and given that the Pantanal is facing the ever-increasing threat of habitat conversion (Harris et al., 2005; Roque et al., 2016), conservation of self-sustaining carnivore populations in the region relies heavily on this protected network and a considerable knowledge about species generated from it, which has largely been provided by camera trapping surveys. 


\section{Conclusions}

Camera trapping allowed us to establish the occurrence of the majority of the Pantanal's carnivore species in Amolar Mountain Ridge. Moreover, we found this tool to be essential for detecting secretive and nocturnal species, which otherwise would be difficult to observe using a diurnal census. As demonstrated by this study and others, camera trapping provides useful information about carnivore activity patterns and temporal interactions, enhancing our knowledge of their ecological requirements and providing information that can be applied to regional conservation plans.

\section{Acknowledgements}

This study was supported by MMX Mineração e Metálicos - EBX Holding Brazil, FCT - Fundação para a Ciência e Tecnologia de Portugal, Instituto Homem Pantaneiro (IHP), and the Department of Biology and Wildlife Conservation of Aveiro University. FCT provided a scholarship grant to the first author (SFRH/BD/51033/2010). This study was co-supported by European Funds through COMPETE and by National Funds through the Portuguese Science Foundation (FCT) within the project UID/ AMB/50017/2013. We thank Teresa Bracher and the staff of IHP for field and office assistance. Special thanks to Arackén Porfirio, Nilson Xavier-Filho, André Brandão, André Coelho, and Erison Monteiro for their invaluable assistance during the field campaigns; to Fernando Tortato, Rafael Hoogesteijn and Panthera for lending camera traps to cover the study site; and to John O'Brien for proofreading the manuscript.

\section{References}

Alho C.J.R., Sabino J. 2011. A conservation agenda for the Pantanal's biodiversity. Brazilian Journal of Biology 71(1): 327-335. DOI: 10.1590/S151969842011000200012

Alho C.J.R., Camargo G., Fischer, E. 2011. Terrestrial and aquatic mammals of the Pantanal. Brazilian Journal of Biology 71(1): 297-310. DOI: 10.1590/S151969842011000200009

Asensio N., Gómez-Marín F. 2002. Interspecific interaction and predator avoidance behavior in response to tayra (Eira barbara) by mantled howler monkeys (Alouatta palliata). Primates 43(4): 339-341. DOI: 10.1007/ BF02629607

Bertassoni A., Xavier-Filho N.L., Rabelo F.A., Leal S.P.S., Porfirio G.E.O., Moreira V.F., Rabelo A.P.C. 2012. Paraguay River environmental monitoring by Rede de Proteção e Conservação da Serra do Amolar, Pantanal, Brazil. Pan-American Journal of Aquatic Sciences 7(2): 77-84.

Bianchi R.C., Campos R.C., Xavier-Filho N.L., Olifiers N., Gompper M.E., Mourão G. 2014. Intraspecific, interspecific, and seasonal differences in the diet of three mid-sized carnivores in a large Neotropical wetland. Acta Theriologica 59(1): 13-23. DOI: 10.1007/s13364-013-0137-x

Bianchi R.C., Olifiers N., Gompper M.E., Mourão G. 2016. Niche partitioning among mesocarnivores in a Brazilian wetland. PLoS ONE 11(9): e0162893. DOI: 10.1371/ journal.pone.0162893

Bowler M.T., Tobler M.W., Endress B.A., Gilmore M.P., Anderson M.J. 2017. Estimating mammalian species richness and occupancy in tropical forest canopies with arboreal camera traps. Remote Sensing in Ecology and Conservation 3(3): 146-157. DOI: 10.1002/rse2.35

Cadavid-Garcia E.A. 1984. O clima no Pantanal Mato-grossense. Brasília: Embrapa CPAP. 42 p.

Carvalho W.D., Adania C.H., Esbérard C.E.L. 2013. Comparison of two mammalian surveys made with camera traps in southeastern Brazil, focusing on the abundance of wild mammals and domestic dogs. Brazilian Journal of Biology 73(1): 29-36. DOI: 10.1590/ S1519-69842013000100005

Crawshaw P.G., Quigley H.B. 1991. Jaguar spacing, activity and habitat use in a seasonally flooded environment in Brazil. Journal of Zoology 223: 357-370. DOI: 10.1111/j.1469-7998.1991.tb04770.x

Cruz J., Sarmento P., White P.C.L. 2015. Influence of exotic forest plantations on occupancy and co-occurrence patterns in a Mediterranean carnivore guild. Journal of Mammalogy 96(4): 854-865. DOI:10.1093/jmammal/gyv109

De Ângelo C., Paviolo A., Di Bitetti M. 2011. Differential impact of landscape transformation on pumas (Puma concolor) and jaguars (Panthera onca) in the Upper Paraná Atlantic Forest. Diversity and Distributions 17(3): 422-436. DOI: 10.1111/j.14724642.2011.00746.x

De la Torre J.A., Núñez J.M., Medellín R.A. 2017. Spatial requirements of jaguars and pumas in Southern Mexico. Mammalian Biology - Zeitschrift für Säugetierkunde 84: 52-60. DOI: 10.1016/j.mambio.2017.01.006

Di Bitetti M.S., Paviolo A., De Angelo C. 2006. Density, habitat use and activity patterns of ocelots (Leopardus pardalis) in the Atlantic Forest of Misiones, Argentina. Journal of Zoology 270(1): 153-163. DOI: 10.1111/j.1469-7998.2006.00102.x

Di Bitetti M.S., Di Blanco Y.E., Pereira J.A., Paviolo A., Pérez I.J. 2009. Time partitioning favours the coexistence of sympatric crab-eating-foxes (Cerdocyon thous) and pampas foxes (Lycalopex gymnocercus). Journal of Mammalogy 90(2): 479-490. DOI: 10.1644/08-MAMM-A-113.1

Di Bitetti M.S., De Angelo C.D., Di Blanco Y.E., Paviolo A. 2010. Niche partitioning and species coexistence in a Neotropical felid assemblage. Acta Oecologica 36(4): 403-412. DOI10.1016/j.actao.2010.04.001

Eisenberg J.F., Redford K.H. 1999. Mammals of the Neotropics - The Central Neotropics (Ecuador, Peru, Bolivia, Brazil). Chicago: University of Chicago Press. 609 p.

Emmons L.H. 1987. Comparative feeding ecology of felids in a Neotropical rainforest. Behavioral Ecology and Sociobiology 20(4): 271-283. DOI: 10.1007/BF00292180 
Foster V.C., Sarmento P., Sollmann R., Tôrres N., Jácomo A.T.A., Negrões N., Fonseca C., Silveira L. 2013. Jaguar and puma activity patterns and predator-prey interactions in four Brazilian biomes. Biotropica 45(3): 373-379. DOI: 10.1111/btp.12021.

Frey S., Fisher J.T., Burton A.C., Volpe J.P. 2017. Investigating animal activity patterns and temporal niche partitioning using camera-trap data: challenges and opportunities. Remote Sensing in Ecology and Conservation 3(3): 123-132. DOI: 10.1002/rse2.60

Gómez H., Wallace R.B., Ayala G., Tejada R. 2005. Dry season activity periods of some Amazonian mammals. Studies on Neotropical Fauna and Environment 40(2): 91-95. DOI: 10.1080/01650520500129638

Harmsen B.J., Foster R.J., Silver S.C., Ostro L.E.T., Doncaster C.P. 2009. Spatial and temporal interactions of sympatric jaguars (Panthera onca) and pumas (Puma concolor) in a Neotropical forest. Journal of Mammalogy 90(3): 612 620. DOI: 10.1644/08-MAMM-A-140R.1

Harmsen B.J., Foster R.J., Silver S., Ostro L., Doncaster P. 2010. Differential use of trails by forest mammals and the implications for camera trap studies: a case study from Belize. Biotropica 42(1):126-133. DOI: 10.1111/j.1744-7429.2009.00544.X

Harmsen B.J., Foster R.J., Silver S.C., Ostro L.E.T., Doncaster C.P. 2011. Jaguar and puma activity patterns in relation to their main prey. Mammalian Biology - Zeitschrift für Säugetierkunde 76(3): 320-324. DOI:10.1016/j.mambio.2010.08.007

Harris M., Tomas W.M., Mourão G., Silva C.J., Guimarães E., Somoda F., Fachim E. 2005. Desafios para proteger o Pantanal Brasileiro: ameaças e iniciativas em conservação. Megadiversidade 1(1): 156-164.

ICMBio. 2016. Brazil Red Book of threatened species of fauna. Brasília: Instituto Chico Mendes de Conservação da Biodiversidade.

IUCN. 2018. IUCN Red List of Threatened Species. Version 2017-3. Available from: http://www.iucnredlist.org

Junk W.J., Cunha C.N., Wantzen K.M., Petermann P., Strussmann C., Marques M.I., Adis J. 2006. Biodiversity and its conservation in the Pantanal of Mato Grosso, Brazil. Aquatic Sciences 68(3): 278-309. DOI: 10.1007/ s00027-006-0851-4

Kolowski J.M., Alonso A. 2010. Density and activity patterns of ocelots (Leopardus pardalis) in northern Peru and the impact of oil exploration. Biological Conservation 143(4): 917-925. DOI: 10.1016/j.biocon.2009.12.039

Leuchtenberger C., Zucco C.A., Ribas C., Magnusson W., Mourão G. 2014. Activity patterns of giant otters recorded by telemetry and camera traps. Ethology Ecology \& Evolution 26(1): 19-28. DOI: 10.1080/03949370.2013.821673

Lima-Borges P.A., Tomas W.M. 2004. Guia de rastros e outros vestígios de mamíferos do Pantanal. Corumbá: Embrapa Pantanal. 148 p.

Lourival R., Drechsler M., Watts M.E., Game E.T., Possingham H. P. 2011. Planning for reserve adequacy in dynamic landscapes; maximizing future representation of vegetation communities under flood disturbance in the Pantanal wetland. Diversity and Distributions 17(2): 297-310. DOI: 10.1111/j.1472-4642.2010.00722.x

Loveridge A.J., Wang S.W., Frank L.G., Seidensticker J. 2010. People and wild felids: conservation of cats and management of conflicts. In: D.W. Macdonald, A.J. Loveridge (Eds.): Biology and Conservation of Wild Felids. Oxford: Oxford University Press. P. 161-195.

Lucherini M., Reppucci J.I., Walker R.S., Villalba M.L., Wurstten A., Gallardo G., Iriarte A., Villalobos R., Perovic P. 2009. Activity pattern segregation of carnivores in the high Andes. Journal of Mammalogy 90(6): 1404-1409. DOI: 10.1644/09-MAMM-A-002R.1

Lyra-Jorge M.C., Ciocheti G., Pivello V.R., Meirelles S.T. 2008. Comparing methods for sampling large and medium sized mammals: camera traps and track plots. European Journal of Wildlife Research 54: 739-744. DOI: 10.1007/s10344-008-0205-8

Mackenzie D.I., Royle J.A. 2005. Designing efficient occupancy studies: general advice and tips on allocation of survey effort. Journal of Applied Ecology 42: 1105 1114. DOI: 10.1111/j.1365-2664.2005.01098.x

Mackenzie D.I., Nichols J.D., Lachman G.B., Droege S., Royle A., Langtimm C.A. 2002. Estimating site occupancy rates whendetectionprobabilitiesareless thanone.Ecology83(8): 2248-2255.DOI: 10.1890/0012-9658(2002)083[2248:ESORWD]2.0.CO;2

Mackenzie D.I., Nichols J.D., Royle J.A, Pollock K.P., Bailey L.L., Hines, J.E. 2006. Occupancy estimation and modeling: inferring patterns and dynamics of species occurrence. San Diego: Academic Press. 631 p.

Maffei L., Cuéllar E., Noss A.J. 2002. Using camera-traps to assess mammals in the Chaco-Chiquitano ecotone. Revista Boliviana Ecológica 11: 55-65.

McCarthy J.L., Wibisono H.T., McCarthy K.P., Fuller T.K., Andayani N. 2015. Assessing the distribution and habitat use of four felid species in Bukit Barisan Selatan National Park, Sumatra, Indonesia. Global Ecology and Conservation 3: 210-221. DOI: 10.1016/j. gecco.2014.11.009

MMA - Ministério do Meio Ambiente. 2006. Caderno da Região Hidrográfica do Paraguai. Ministério do Meio Ambiente, Secretaria de Recursos Hídricos. Brasília: MMA. 142 p.

MMA - Ministério do Meio Ambiente. 2007. Areas prioritárias para a Conservação, Uso Sustentável, e Repartição de Benefícios da Biodiversidade Brasileira. Brasília: MMA. $301 \mathrm{p}$.

Monroy-Vilchis O., Rodríguez-Soto C., Zarco-González M., Urios V. 2009. Cougar and jaguar habitat use and activity patterns in central Mexico. Animal Biology 59(2): 145-157. DOI:10.1163/157075609X437673

Moreira V.F. 2011. Rede de Proteção e Conservação da Serra do Amolar: rompendo fronteiras para a conservação do Pantanal. MSc Thesis. Campo Grande: Universidade Federal de Mato Grosso do Sul. 76 p.

Núñez R., Miller B., Lindzey F. 2000. Food habits of jaguars and pumas in Jalisco, Mexico. Journal of 
Zoology 252(3): 373-379. DOI: 10.1111/j.14697998.2000.tb00632.x

O’Connell A.F., Talancy N.W., Bailey L.L., Sauer J.R., Cook R., Gilbert A.T. 2006. Estimating site occupancy and detection probability parameters for meso and large mammals in a coastal ecosystem. Journal of Wildlife Management 70(6): 1625-1633. DOI: 10.2193/0022-541X( 2006)70[1625:ESOADP]2.0.CO;2

Oliveira-Santos L.G.R., Tortato M.A., Graipel M.E. 2008. Activity pattern of Atlantic Forest small arboreal mammals as revealed by camera traps. Journal of Tropical Ecology 24(5): 563-567. DOI: 10.1017/ S0266467408005324

Porfirio G., Sarmento P., Xavier Filho N.L., Cruz J., Fonseca C. 2014. Medium to large size mammals of southern Serra do Amolar, Mato Grosso do Sul, Brazilian Pantanal. CheckList 10(3): 473-482. DOI: 10.15560/10.3.473

Porfirio G., Foster V.C., Fonseca C., Sarmento P. $2016 \mathrm{a}$. Activity patterns of ocelots and their potential prey in the Brazilian Pantanal. Mammalian Biology-Zeitschrift für Säugetierkunde 81(5): 511-517. DOI: 10.1016/j. mambio.2016.06.006

Porfirio G., Sarmento P., Leal S., Fonseca C. 2016b. How is the jaguar Panthera onca perceived by local communities along the Paraguai River in the Brazilian Pantanal? Oryx 50(1): 163-168. DOI: 10.1017/S0030605314000349

Porfirio G., Sarmento P., Foster V., Fonseca C. 2017. Activity patterns of jaguars and pumas and their relationship to those of their potential prey in the Brazilian Pantanal. Mammalia 81(4): 401-404. DOI: 10.1515/mammalia-2015-0175

R Development Core Team. 2013. R: A Language and Environment for Statistical Computing Version 3.0.0. Available from: www.R-project.org

Rich L.N., Russell R.E., Glenn E., Mitchell M.S., Gude J.A., Podruzny K.M., Sime C.A., Laudon K., Ausband D.E., Nichols J.D. 2013. Estimating occupancy and predicting numbers of gray wolf packs in Montana using hunter surveys. Journal of Wildlife Management 77(6): 1280-1289. DOI: 10.1002/jwmg.562

Ridout M.S., Linkie M. 2009. Estimating overlap of daily activity patterns from camera trap data. Journal of Agricultural, Biological, and Environmental Statistics 14(3): 322-337. DOI: 10.1198/jabes.2009.08038

Romero-Muñoz A., Maffei L., Cuéllar E., Noss A.J. 2010. Temporal separation between jaguar and puma in the dry forests of Southern Bolivia. Journal of Tropical Ecology 26(3): 303-311. DOI: 10.1017/S0266467410000052

Roque F.O., Ochoa-Quintero J., Ribeiro D.B., Sugai L.S., Costa-Pereira R., Lourival R., Bino G. 2016. Upland habitat loss as a threat to Pantanal wetlands. Conservation Biology 30(5): 1131-1134. DOI: 10.1111/cobi.12713

Ross J., Hearn A.J., Johnson P.J., Macdonald D.W. 2013. Activity patterns and temporal avoidance by prey in response to Sunda clouded leopard predation risk. Journal of Zoology 290(2): 96-106. DOI: 10.1111/jzo.12018

Royle J.A., Nichols J.D. 2003. Estimating abundance from repeated presence absence data or point counts. Ecology 84(3): 777-790. DOI: 10.1890/0012-9658(2003)084[0777:EAFRPA]2.0.CO;2

Royle A.J., Nichols J.D., Kéry M. 2005. Modelling occurrence and abundance of species when detection is imperfect. Oikos 110(2): 353-359. DOI: 10.1111/j.00301299.2005.13534.x

Sarmento P., Cruz J., Eira C., Fonseca C. 2009. Spatial colonization by feral domestic cats Felis catus of former wildcat Felis silvestris silvestris home ranges. Acta Theriologica 54(1): 31-38. DOI: 10.1007/BF03193135

Sarmento P., Cruz J., Eira C., Fonseca C. 2011. Modeling the occupancy of sympatric carnivorans in a Mediterranean ecosystem. European Journal of Wildlife Research 57(1):119-131. DOI: 10.1007/s10344-010-0405-x

Seidl A.F., Silva J.S.V., Moraes A.S. 2001. Cattle ranching and deforestation in the Brazilian Pantanal. Ecological Economics 36(3): 413-425. DOI: 10.1016/S09218009(00)00238-X

Sillero-Zubiri C., Hoffmann M., Macdonald D.W. 2004 Canids: foxes, wolves, jackals, and dogs: status survey and conservation action plan. Gland, Switzerland and Cambridge, UK: IUCN/SSC Canid Specialist Group. 430 p.

Silveira L., Jácomo A.T.A., Diniz-Filho A.F. 2003. Camera trap, line transect census and track surveys: a comparative evaluation. Biological Conservation 114(3): 351355. DOI: 10.1016/S0006-3207(03)00063-6

Sollmann R., Furtado M.M., Hofer H., Jácomo A.T.A., Tôrres N.M., Silveira L. 2012. Using occupancy models to investigate space partitioning between two sympatric large predators, the jaguar and puma in central Brazil. Mammalian Biology - Zeitschrift für Säugetierkunde 77(1): 41-46. DOI: 10.1016/j.mambio.2011.06.011

Srbek-Araujo A.C., Chiarello A.G. 2005. Is camera-trapping an efficient method for surveying mammals in Neotropical forests? A case study in south-eastern Brazil. Journal of Tropical Ecology 21(1): 121-125. DOI: 10.1017/ S0266467404001956

Surnato S., Sollmann R., Mohamed A., Kelly M.J. 2013. Camera trapping for the study and conservation of tropical carnivores. Raffles Bulletin of Zoology 28: 21-42.

Taber A.B., Novaro A.J., Neris N., Colman F.H. 1997. The food habits of sympatric jaguar and puma in the Paraguayan Chaco. Biotropica 29(2): 204-213. DOI: 10.1111/j.1744-7429.1997.tb00025.x

Tobler M.W., Carrillo-Percastegui S.E., Pitman R.L., Mares R., Powell G. 2008. Further notes on the analysis of mammal inventory data collected with camera traps. Animal Conservation 11(3): 187-189. DOI: 10.1111/j.1469-1795.2008.00181.x

Vieira E.M., Port D. 2007. Niche overlap and resource partitioning between two sympatric fox species in southern Brazil. Journal of Zoology 272(1): 57-63. DOI: 10.1111/j.1469-7998.2006.00237.x

Zimmermann A., Walpole M.J., Leader-Williams N. 2005. Cattle ranchers' attitudes to conflicts with jaguars in the Pantanal of Brazil. Oryx 39(4): 406-412. DOI: 10.1017/ S0030605305000992 


\title{
ФОТОЛОВУШКИ КАК ИНСТРУМЕНТ ДЛЯ ОХРАНЫ ХИЩНЫХ МЛЕКОПИТАЮЩИХ В СЕТИ ОСОБО ОХРАНЯЕМЫХ ПРИРОДНЫХ ТЕРРИТОРИЙ ПАНТАНАЛА (БРАЗИЛИЯ)
}

\author{
Г. Порфирио ${ }^{1,2 *}$ В. К. Фостер ${ }^{3}$, П. Сарменто ${ }^{1}$ К. Фонсека ${ }^{1}$ \\ ${ }^{1}$ Университет Авейру, Португалия \\ e-mail: sarmentop@gmail.com,cfonseca@ua.pt \\ ${ }^{2}$ Католический университет Дом Боско, Бразилия \\ e-mail:*grasi_porfirio@hotmail.com \\ ${ }^{3}$ Федеральный университет Мату-Гросу-ду-Сул, Бразилия \\ e-mail:vaniafoster@hotmail.com
}

\begin{abstract}
Хотя бразильский Пантанал известен во всем мире своим биоразнообразием, лишь около 5\% которого находится под охраной. Сеть по охране и сохранению горного хребта Амолар является неофициаль-

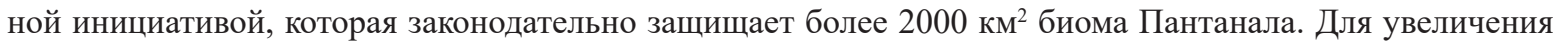
познания о разнообразии видов и их экологических требований с августа 2011 г. по сентябрь 2013 г. на хребте Амолар-Маунтин были проведены несколько обследований с использованием фотоловушек. Целью этого исследования было: 1) провести инвентаризацию видов хищных млекопитающих, встречающихся в пределах этой сети особо охраняемых природных территорий (ООПТ); 2) описать модели их активности; 3) обсудить угрозы для сохранения этих видов в регионе. Мы использовали метод ядерной оценки плотности распределения плотности для описания моделей активности видов. Мы получили 764 записи (за 12703 фотоловушко-дня) для восьми хищных млекопитающих, в том числе находящихся под угрозой исчезновения видов в Бразилии. Среди них - ягуар (Panthera onca), пума (Puma concolor) и оцелот (Leopardus pardalis) - одни из наиболее часто регистрируемых фотоловушками видов. Из других зарегистрированных видов - это обыкновенная носуха (Nasua nasua), тайра (Eira barbara), енот-ракоед (Procyon cancrivorus) и ягуарунди (Puma yagouaroundi). Мы представили информацию о моделях активности животных. Ягуар и пума проявляли катемеральную активность. Оцелот и енот-ракоед были преимущественно ночными животными. Обыкновенная носуха и ягуарунди проявили круглосуточную активность. Лазающие животные и виды с естественной низкой плотностью, такие как тайра и енотракоед, были трудно обнаруживаемыми с использованием фотоловушек. Тем не менее, из-за природных особенностей области исследования метод фотоловушек является одним из наиболее подходящих инструментов для получения данных о хищных млекопитающих и их добыче. Эта информация имеет важное значение в планировании охраны природных объектов горного хребта Амолар.
\end{abstract}

Ключевые слова: биология сохранения, инвентаризация видов, метод фотоловушек, модель активности, хищные млекопитающие 